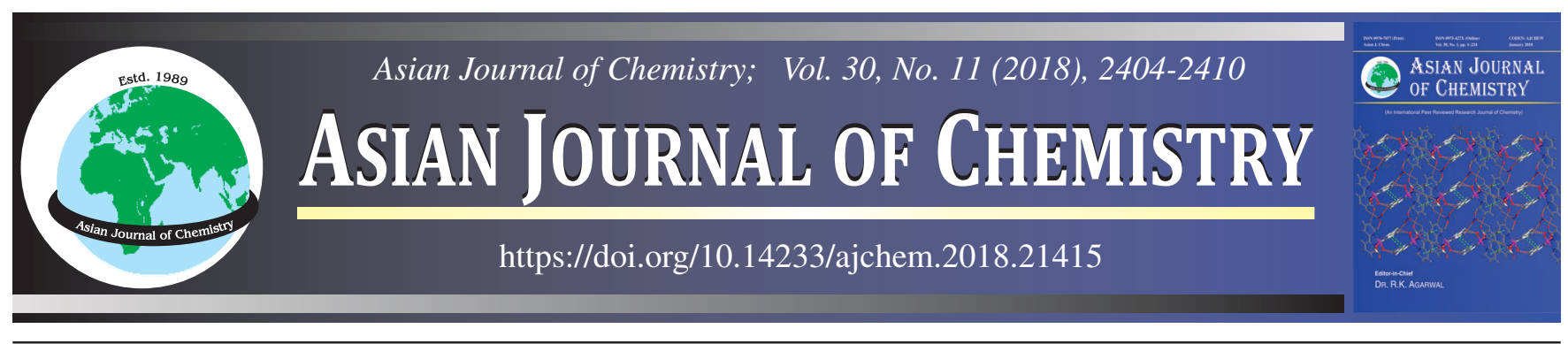

\title{
Micro-Structural Characterization of Activating Solution with Siliceous Species on Chemical Reactivity of Geopolymer by Advanced Analytical Techniques
}

\author{
T. REVATHI ${ }^{1,2}$, R. JEYALAKShMI ${ }^{2, *}$ and N.P. RAJAMANE ${ }^{1}$
}

${ }^{1}$ Centre for Advanced Concrete Research, SRM University, Kattankulathur-603 203, India

${ }^{2}$ Department of Chemistry, SRM University, Kattankulathur-603 203, India

*Corresponding author: E-mail: rajyashree64@gmail.com

Received: 30 April 2018;

Accepted: 14 June 2018;

Published online: 27 September 2018;

AJC-19084

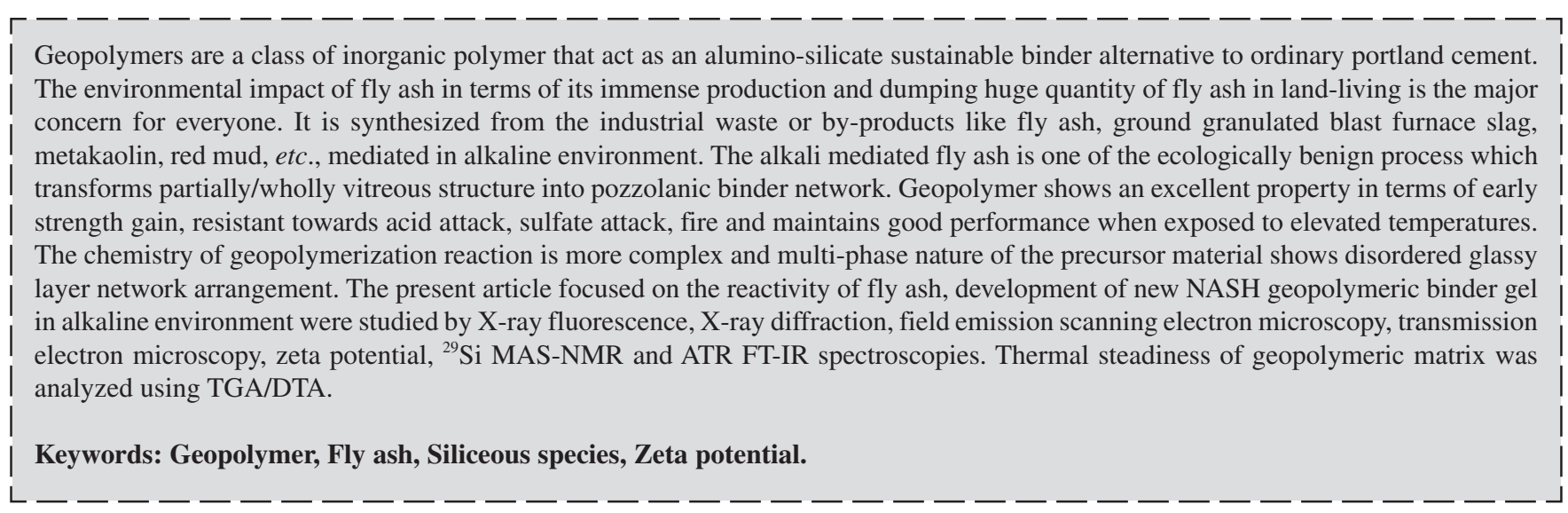

\section{INTRODUCTION}

Cement plays an important role in construction and national economic development and it is also considered as second to the fresh water as the most widely used commodity $[1,2]$. An alarming issue was identified with the cement-based material for the development of sustainable infrastructure in a carbon embarrassed society. About two billion tonnes of $\mathrm{CO}_{2}$ emitted from cement manufacturing process per year (which is around 5-7 \% of the global anthropogenic $\mathrm{CO}_{2}$ emission) including emissions of harmful particulates [3-5]. In search for cement less alternative binder which opens an opportunity for the development of the alkali activated materials. Geopolymers, a subset of alkali activated materials [4,6,7] are systems of inorganic binders proposed by Davidovits in 1970's [8]. The geopolymeric main reaction product (N-A-S-H network formation) formed by treating industrial waste/by product with a hybrid solution of $\mathrm{NaOH}$ and $\mathrm{Na}_{2} \mathrm{SiO}_{3}$ solution. The industrial waste/by product used for the synthesis of geopolymer are fly ash, ground granulated blast furnace slag (GGBS), copper slag, red mud, rice husk ash, etc.

The chemistry of geopolymerization reaction and strength development of geopolymeric mortar (product) are influenced by different features such as chemical composition of precursor materials, activator solution, water content, type of aggregates, additives and curing conditions [9]. Several studies have been conducted to investigate fly ash based geopolymer concrete properties [10]. The strength development of fly ash based geopolymer depend upon the particle size, glassy phase content, amorphous silicon and aluminium, chemical composition, combination of activators, concentration of activator solution and curing conditions [10]. The first phase of geopolymerization reaction depends on the activator solution, Fly ash can be activated by both $\mathrm{NaOH}, \mathrm{Na}_{2} \mathrm{SiO}_{3}$ or by using hybrid solution of $\mathrm{NaOH}$ $+\mathrm{Na}_{2} \mathrm{SiO}_{3}$. Sodium hydroxide activation results in increased dissolution of aluminium monomeric species rather than silicon

This is an open access journal, and articles are distributed under the terms of the Creative Commons Attribution-NonCommercial 4.0 International (CC BY-NC 4.0) License, which allows others to copy and redistribute the material in any medium or format, remix, transform, and build upon the material, as long as appropriate credit is given and the new creations are licensed under the identical terms. 
resulting in aluminium rich geopolymeric network formation and its negative charge created by the aluminium was counter balanced by sodium ions from the activator solution. The commercially available sodium silicate (molar ratio:2.0,2.4,3.2) used as an activator solution results in decrease in mechanical strength due to presence of $\mathrm{Q}^{3}$ and $\mathrm{Q}^{4}$ structural unit in the activating solution. A hybrid solution of $\mathrm{NaOH}+\mathrm{Na}_{2} \mathrm{SiO}_{3}$ results in enhancement in the development of 3D sodium alumino silicate hydrate gel (N-A-S-H) which reflects in the mechanical strength. The second phase of reaction depends on the curing temperature in the range $60-95^{\circ} \mathrm{C}$ and curing time (24-48 h). The curing condition alters the dissolution rate of monomeric species from the precursor material followed by condensation, polymerization in terms of $\mathrm{Si} / \mathrm{Al}$ over time which will change the network formation of geopolymers. Many researchers reported that the fly ash based geopolymer has significant resistance towards acid, sulfate attack and fire resistant. Geopolymer can be formulated any specific niche applications by optimizing the influencing parameters $[5,11,12]$. Till now there is no simple methodology or analytical tool for evaluating the chemical composition, network formation, amorphous content, degree of reaction of the precursor material, activator solution and formed geopolymeric gel. Hence, it is understood that synthesized technique can be succeeded to produce the predicted fly ash based geopolymer characteristics in the most practicable means possible.

To sightsee the probable utilization of industrial by product form the thermal power plant, fly ash in geopolymer technology were evaluated after chemical characterization and fly ash reactivity. The present study focused on the chemical, mineralogical and microstructural description of fly ash based geopolymer using NMR, FTIR, TGA/DTA, zeta potential, FESEM and TEM techniques.

\section{EXPERIMENTAL}

Raw materials: Fly ash from Ennore thermal power plant, India was used as the precursor material and its chemical composition was determined by means of energy dispersive X-ray fluorescence spectroscopy (EDXRF) and its physico-chemical properties is tabulated in Table-1. Sodium silicate solution was used as alkali activator (AS) $\left(15 \% \mathrm{Na}_{2} \mathrm{O}, 33 \% \mathrm{SiO}_{2}\right.$ and $52 \%$ $\mathrm{H}_{2} \mathrm{O}$ ). Starting sodium silicate was further adjusted by adding lye $(50 \% \mathrm{NaOH})$. An hybrid activator solution obtained by mixing of sodium hydroxide (50\%) and final modulus of the activator solution is 1.1 and it comprises $\mathrm{SiO}_{2}$ content of 26.5 $\pm 0.8 \%, \mathrm{Na}_{2} \mathrm{O}: 18.9 \pm 0.6 \%$, residual $\mathrm{H}_{2} \mathrm{O}$ and kept at $24 \mathrm{~h}$ prior to use.

Geopolymer synthesis: The geopolymer paste and mortar was synthesized by mixing alkali activator solution $\left(\mathrm{Na}_{2} \mathrm{SiO}_{3} /\right.$ $\mathrm{NaOH}=1.1$ ) with the calculated quantity of precursor material (Table-2). All the dry samples were mixed for 4-8 $\mathrm{min}$ in the DIGI mortar mixer machine followed by activator solution. This paste mixture was transferred into the cubical moulds $(50 \mathrm{~mm}$ $\times 50 \mathrm{~mm} \times 50 \mathrm{~mm}$ ) vibrated for compaction and sealed with a plastic cover to minimize loss of evaporable water followed by heat curing at $60^{\circ} \mathrm{C}$ for $24 \mathrm{~h}$. A 28 days, cured specimens are further used for the microstructural analysis.

Natural sand obtained from the river bed is used as a granular filler material (fine aggregate) with the specific gravity 2.58 and finess modulus 3.01 is used as fine aggregate and confirmed by Grading Zone II of IS 383: 1970. The geopolymer mortars were prepared by mixing the siliceous sand with the binder (2:1) and homogenization of the material is obtained at a speed of $110 \mathrm{rpm}$ in the DIGI mortar machine for $5 \mathrm{~min}$ and casted in cylindrical mould with the size of $75 \mathrm{~mm}$ diameter $\times 150 \mathrm{~mm}$ height are used to study mechanical strength property. After $24 \mathrm{~h}$ of casting, cylindrical moulds containing geopolymer mortar matrix were kept for heat curing at $60^{\circ} \mathrm{C}$ for a period of $24 \mathrm{~h}$ in a hot air oven. To study the compressive strength of specimen the wet matrix casted into the cylindrical tube $(75 \mathrm{~mm}$ dia. $\times$ $150 \mathrm{~mm}$ height).

${ }^{29} \mathrm{Si}$-NMR spectroscopy: High resolution MAS- ${ }^{29} \mathrm{Si}$ NMR performed on powder sample at room temperature on Brucker ADVANCE-400 spectrometer operating at $72.18 \mathrm{MHz}$ with.7 $\mathrm{mm}$ probe, a $5 \mathrm{~mm}$ zirconia rotor. Typically $500-600$ scans with a pulse width of $2.2 \mu \mathrm{s}$ and the relaxation delay of $22 \mathrm{~s}$ for data collection of each sample and the standard used is TMS (0 ppm).

ATR FT-IR: The bonding nature of geopolymer paste, precursor material and activator solution was characterized using ATR FT-IR technique. The spectra were recorded on a Bruker IFS 66v/S FT-IR spectrometer equipped with a DTGS detector and a vertical ATR accessory. The vertical ATR accessory consisted of a trapezoidal-shaped $\mathrm{ZnSeIRE}\left(45^{\circ}, 50 \mathrm{~mm} \times 20 \mathrm{~mm}\right.$

TABLE-1

PHYSICAL AND CHEMICAL PROPERTIES OF FLY ASH

\begin{tabular}{cccccccc}
\hline $\begin{array}{c}\text { Chemical } \\
\text { composition (wt. \%) }\end{array}$ & $\mathrm{SiO}_{2}$ & $\mathrm{Al}_{2} \mathrm{O}_{3}$ & $\mathrm{CaO}$ & $\mathrm{Fe}_{2} \mathrm{O}_{3}$ & $\mathrm{~K}_{2} \mathrm{O}$ & $\mathrm{MgO}$ & 0.015 \\
\hline Fly ash & 44.98 & 24.45 & 3.599 & 18.17 & 4.65 & 0.5 \\
\hline Physical properties & $\begin{array}{c}\text { Specific } \\
\text { gravity }\end{array}$ & $\begin{array}{c}\text { Fine modulus } \\
(\text { Blaine })\left(\mathrm{m}^{2} / \mathrm{kg}\right)\end{array}$ & $\begin{array}{c}\text { Bulk density } \\
\left(\mathrm{kg} / \mathrm{m}^{3}\right)\end{array}$ & $\begin{array}{c}\text { Residue on 45- } \\
\text { micron sieve }\end{array}$ & $\begin{array}{c}\text { Cementing efficiency } \\
\text { factor at 28 days }\end{array}$ & $\begin{array}{c}\text { Loss on } \\
\text { ignition }(\%)\end{array}$ \\
\hline Fly ash & 2.15 & 330 & 1005 & 35 & 0.93 & 1.4 \\
\hline
\end{tabular}

TABLE-2

MATERIAL DESIGN OF GEOPOLYMER PASTE, MORTAR

\begin{tabular}{ccccccccc}
\hline \multirow{2}{*}{ Sample type } & \multirow{2}{*}{ Mix ID } & \multicolumn{7}{c}{ Mix quantity (Mortar-2200 g/m ${ }^{3}$ ) } \\
\cline { 3 - 9 } & & Fly ash & GF & $\mathrm{Na}_{2} \mathrm{SiO}_{3}$ & $\mathrm{NaOH}$ & $\mathrm{Na}_{2} \mathrm{SiO}_{3} / \mathrm{NaOH}$ & $\mathrm{L} / \mathrm{B}$ & $\mathrm{AS}$ \\
\hline Paste & $\mathrm{FG}$ & 650 & - & 198 & 50 & 1.5 & 0.4 & 248 \\
Mortar & FGm & 650 & 1209 & 272 & 69 & 1.5 & 0.6 & 341 \\
\hline
\end{tabular}

$\mathrm{GF}=$ Granular filler, $\mathrm{Na}_{2} \mathrm{SiO}_{3}=$ Sodium silicate solution, $\mathrm{NaOH}=$ Sodium hydroxide, $\mathrm{L} / \mathrm{B}=\mathrm{Liquid} /$ Binder, $\mathrm{AS}=\mathrm{Alkaline}$ solution . 
$\times 2 \mathrm{~mm}$ ) with totally 25 internal reflections mounted in a $~ 3.5$ $\mathrm{mL}$ flow-through stainless steel cell. Data evaluation and spectra simulation were performed with OPUS software from Bruker Optics.

Mechanical strength: Mechanical strength property was tested using compression testing machine with a loading rate of $100 \mathrm{~kg} / \mathrm{min}$ (ASTM C109 M). Mechanical properties were tested on the hardened mortar sample after 1, 3, 7, 28, 60, 180 and 365 days. The strengths results reported were the average of five samples.

Mineralogical composition: X-ray diffraction was carried out using PANalytical X'pert Pro X-ray diffractometer with $\mathrm{CuK} \alpha 1.542 \AA$, $30 \mathrm{Ma}$ with $40 \mathrm{kV}$ with step size 0.017 degree/s on the powdered sample of raw material and 28 days of cured fly ash based geopolymer sample.The data obtained from X-ray diffraction studies were interpreted using PCPDFWIN software and reitveld analysis.

Surface morphology: Transmission electron microscopy) was conducted on a JEOL 2010 electron microscope, fitted with a energy dispersive X-ray spectrometer (EDS). Selected area diffraction patterns (SADP) were collected from regions of interest first, followed by image acquisition and finally microanalysis. This order was chosen due to decreasing sensitivity to beam damage through the sequence. Field emission scanning electron microscopy (FESEM) was performed using high resolution field emission electron microscope FEI's Quanta 200 FEGFESEM. The specimen fragments for geopolymer paste mounted in epoxy resin, further vacuumed, operative at an accelerating voltage $24 \mathrm{kV}$ and test was carried out using back scattered electron detectors.

Thermogravimetric analysis: To investigate the strength degradation mechanism of geopolymer binder at high temperature, TGA/DTA were conducted by simultaneous thermal analysis (STA), NETSCH 2500 Regulus in the temperature range $30-1200{ }^{\circ} \mathrm{C}$ in floating air/nitrogen $(60 \mathrm{~mL} / \mathrm{min})$ with the heating rate of $10{ }^{\circ} \mathrm{C} / \mathrm{min}$.

Zeta potential: Malvern Zetasizer (nano series) was used to measure the zeta potential. Geopolymeric matrixes of 0.5 weight $\%$ in deionized water against standard potassium tungstosilicate solution and calculations were made through Zetasizer software.

\section{RESULTS AND DISCUSSION}

${ }^{29}$ Si-NMR spectroscopy: Fig. 1 shows ${ }^{29}$ Si MAS-NMR spectra of fly ash, alkali activator (AS) and fly ash based geopolymer paste. A wide spectrum signal ranged between -80 to $-108 \mathrm{ppm}$ of precursor material (FA) depicts the heterogeneous distribution of silicon structural units due to presence of glassy phase material (mullite, quartz). Spectrum of AS shows an intense peak around -72, -80 and -88 ppm corresponds to $\mathrm{Q}^{0}, \mathrm{Q}^{1}$ and $\mathrm{Q}^{2}$, respectively. It is observed that there is an absence of bridging oxygen atom between the tetrahedra silicate crystal, $\mathrm{Q}^{4}$ [13-18]. Upon activation of fly ash using alkaline solution, the geopolymeric gel with low calcium aluminosilicates i.e. N-A-S-H is formed. The main shift is -94 and $-66 \mathrm{ppm}$ indicated the presence of $\mathrm{Q}^{4}(2 \mathrm{Al})$ and $\mathrm{Q}^{4}(3 \mathrm{Al})$ unit. The shift around $-104 \mathrm{ppm}$ is less represented which corresponds to $\mathrm{Q}^{4}(0 \mathrm{Al})$ during geopolymerization, $\mathrm{Al}$ get penetrated $\left[\mathrm{SiO}_{4}\right]^{4-}$ skeleton. General structure of geopolymer depicted as $\mathrm{Si}^{4+}$ and $\mathrm{Al}^{3+}$ tetrahedrally bonded through sharing of oxygen atoms and the extra negative charge on $\mathrm{AlO}_{4}{ }^{-}$group is balanced by the alkaline cation (typically $\mathrm{Na}^{+}$or $\left.\mathrm{K}^{+}\right)$. The signal above $108 \mathrm{ppm}$ are allotted to different crystalline phases of silicon $\mathrm{Q}^{4}(0 \mathrm{Al})(-113 \mathrm{ppm})[19,20]$.

ATR FT-IR: Fig. 2 shows an ATR FT-IR spectrum of fly ash, alkali activator and fly ash based geo-polymer paste. The band at $1093 \mathrm{~cm}^{-1}$ (s) 1 are corresponds to $\mathrm{T}-\mathrm{O}\left(\mathrm{Si}, \mathrm{Al}^{\mathrm{IV}}\right)-\mathrm{O}-$ $\mathrm{Si}$ ) asymmetricstretching vibrations and represent the fusion of both $\mathrm{Al}-\mathrm{O}$ and $\mathrm{Si}-\mathrm{O}$ symmetric stretching. The vibrational frequency at $908 \mathrm{~cm}^{-1}(\mathrm{~m})$ corresponds to the asymmetric stretching of $\left(\mathrm{Si}, \mathrm{Al}^{\mathrm{IV}}\right)-\mathrm{O}-\mathrm{Si}$ in amorphous glasses, which could be composed of higher $\mathrm{Al}$ concentration $[21,22]$. The $\mathrm{Q}^{\mathrm{n}}$ distribution of siliceous species in the alkaline solution was in the range of 1300-700 $\mathrm{cm}^{-1}$. The band around 1000, 1160 and 820 $\mathrm{cm}^{-1}$ are assigned to the asymmetric stretching vibration of $\mathrm{Si}-\mathrm{O}-\mathrm{Si}\left(\mathrm{Q}^{4}\right), \mathrm{Si}-\mathrm{O}-\mathrm{Si}\left(\mathrm{Q}^{3}\right)$ and $\mathrm{Si}-\mathrm{O}-\mathrm{Si}\left(\mathrm{Q}^{0}\right)$, respectively $[23-$ 26] (Table-3). The silicooxygen ring absorption band was found in the range of $800-500 \mathrm{~cm}^{-1}$. The distinct band at 579 and 643 $\mathrm{cm}^{-1}$ exhibit cyclic ring structure in the fly ash based geopolymer (FG) matrix. A strong shift of band from 1093 to $1003 \mathrm{~cm}^{-1}$ is due to the formation of sodium aluminosilicate gel. The band around 797 and $857 \mathrm{~cm}^{-1}$ are due to incorporation of $\mathrm{Al}$ in -Si-OSi- network and -C-O- stretching from carbonates $[19,21,26]$.
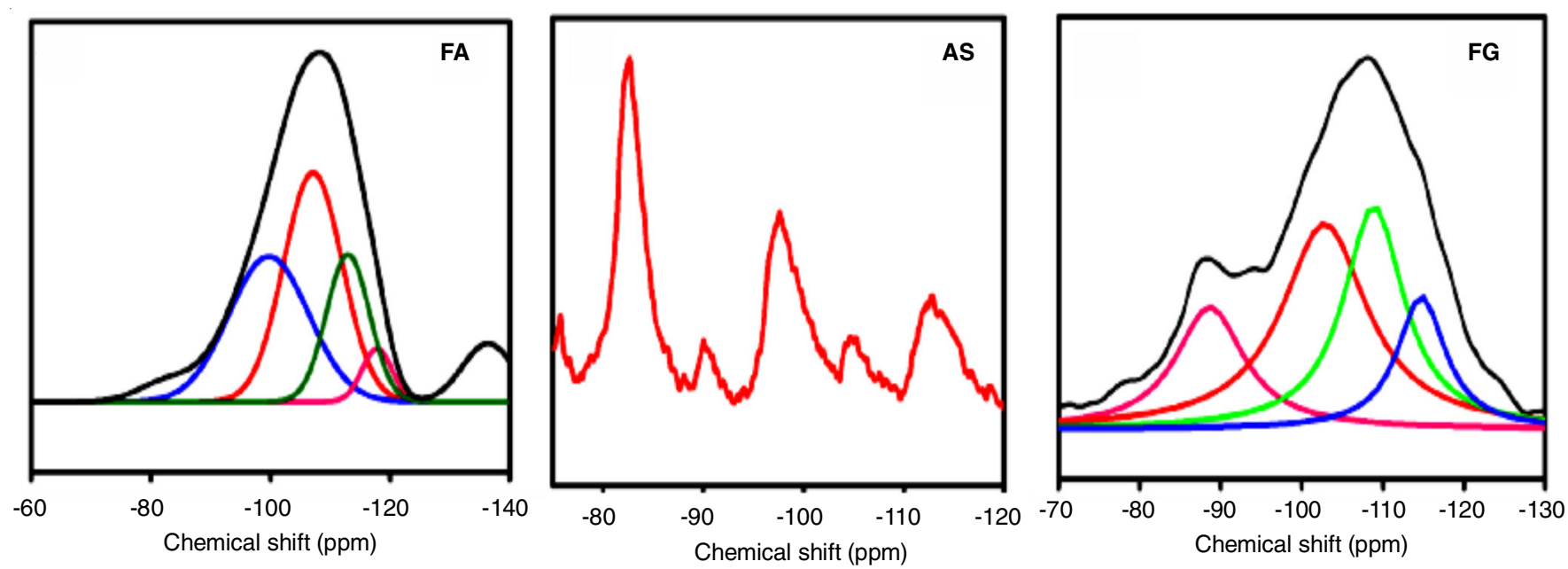

Fig. $1 .{ }^{29}$ Si NMR spectrum of fly ash, alkaline solution (AS), fly ash based geopolymer (FG) 
TABLE-3

MAIN ABSORPTION BANDS $\left(\mathrm{cm}^{-1}\right)$ OF FLY ASH, ALKALINE SOLUTION, FLY ASH BASED GEOPOLYMER SAMPLES

\begin{tabular}{cccl}
\hline & Wavenumber $\left(\mathrm{cm}^{-1}\right)$ & & \multirow{2}{*}{ Attribution } \\
\cline { 1 - 3 } Fly ash & Alkaline solution & Fly ash based geopolymer & \\
\cline { 1 - 3 } $650-500$ & $800-500$ & $600-500$ & Silico-oxygen bond of three, four membered rings \\
$790-730$ & $800-750$ & $800-750$ & Symmetric band of -Si-O-Si-/-Si-O-Al \\
$1250-950$ & $1250-950$ & - & Asymmetric Si-O-Si and/or Al-O-Si stretching \\
- & $1480-1350$ & $1480-1350$ & C-O stretching (carbonates) \\
- & - & $1050-900$ & Sodium alumino silicate gel (NASH) \\
\hline
\end{tabular}

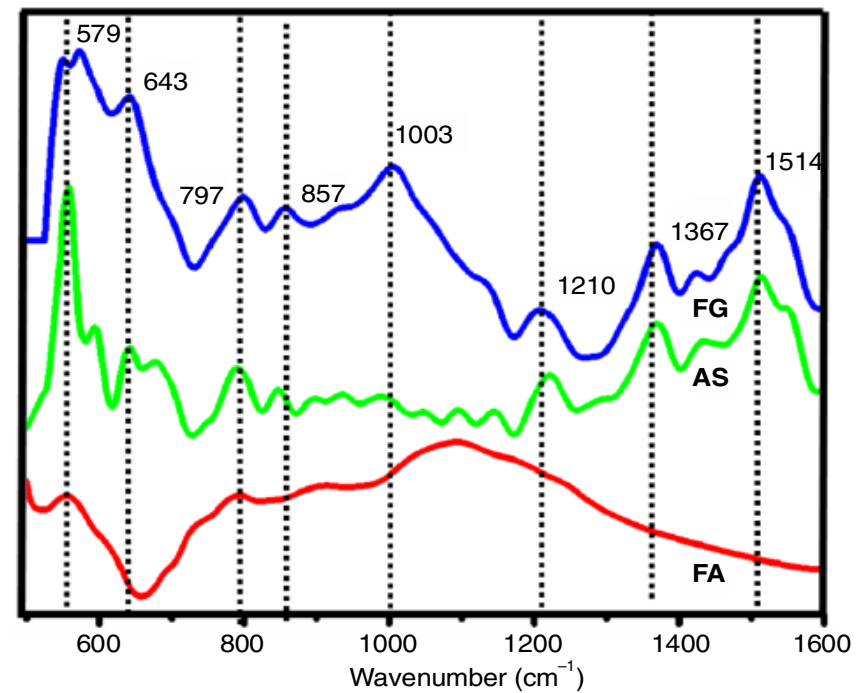

Fig. 2. ATR FT-IR spectrum of fly ash (FG), alkaline solution (AS) and fly ash based geopolymer (FG) samples

Mechanical strength: Fig. 3 shows the compressive strength of fly ash based geopolymer at different ages of curing. The trend is increasing with respect to age of curing. This indicated that long period of curing does not affect the mechanical strength due to the continuous formation of NASH gel. The one-day strength of fly ash based geopolymer specimen is around 8-10 Mpa, which is sufficient for handling and transportation. The fly ash based geopolymer specimen has a boundless implication in the construction sector because of its high mechanical strength and early strength gain property [27]. Abdulkareem et al. [28] reports that 20.3Mpa achieved on the fly ash based geopolymer on 60 days cured samples.

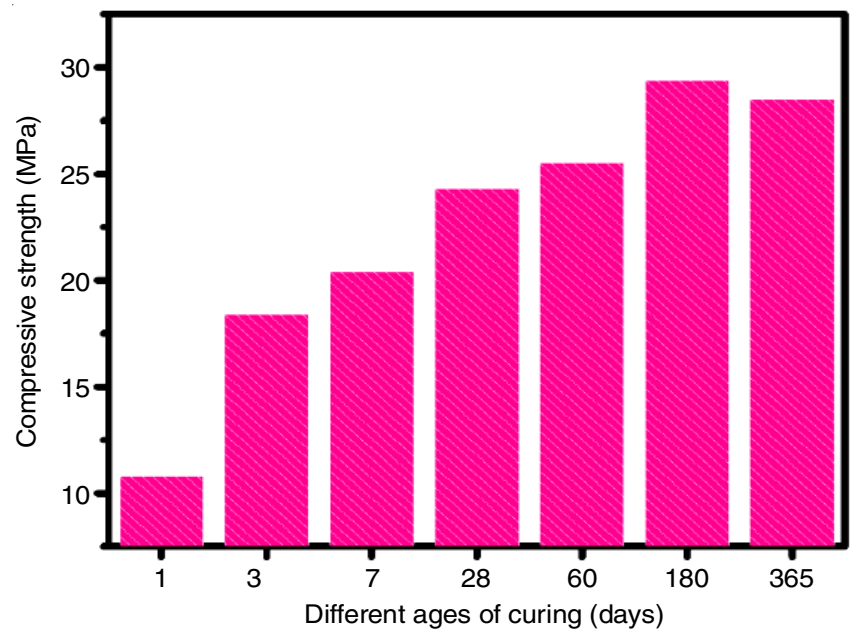

Fig. 3. Compressive strength of FG specimens cured at 1, 3, 7, 28, 60, 180 and 365 days of curing at room temperature
Mineralogical composition: XRD pattern of fly ash shows crystalline phases like mullite (alumina silicate) shows peaks at $25.82^{\circ}, 27.20^{\circ}$ of $2 \theta$ values (d spacing of 3.45 and $3.4 \AA$ ) and the quartz exhibits peaks at $20.73^{\circ}, 26.52^{\circ}, 26.66^{\circ}, 40.66^{\circ}$, $49.96^{\circ}$ of $2 \theta$ values (d spacing of $4.28,3.36,3.34,2.21,1,82$ $\AA$ ) in Fig. 4. There is a broad hump which denotes the presence of amorphous (vitreous) phase in the region between $2 \theta=20$ $25^{\circ}$. The original fly ash contains quartz (Q) and mullite (M) as a main crystalline phase that is about 6\% (Q) and $16.52 \%$ (M) in weight percent as obtained with reitveld method [29] and were neglected for $\mathrm{Si} / \mathrm{Al}$ calculation, since these phases are insoluble during alkali activation. The other phases present in small amounts $(\sim 5 \%)$ are hematite $(2.98 \%)$ and magnetite $(1.99 \%)$.

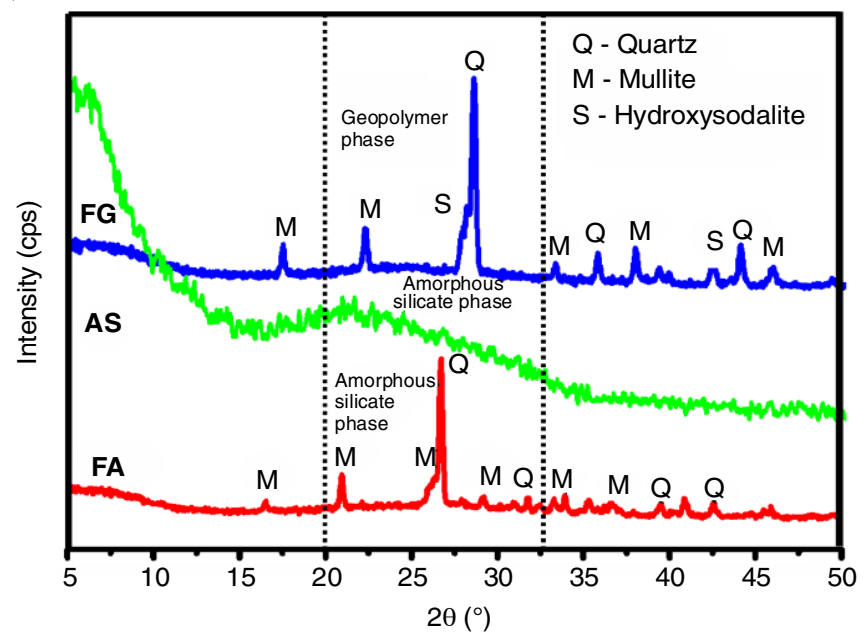

Fig. 4. XRD pattern of fly ash (FA), alkaline solution (AS) and fly ash based geopolymer (FG) samples

The intense peak around $2 \theta=20-30^{\circ}$ was attributed to the presence of amorphous silicate phase containing SiQ4 in the alkaline solution [30]. The quantity of non-bridging oxygen (NBO) in alkaline solution is the function of $\mathrm{SiO}_{2} / \mathrm{Na}_{2} \mathrm{O}$ and the structure of siliceous species will be $\mathrm{SiQ} 3$ and $\mathrm{SiQ} 4$. The hump present in fly ash and alkali activator shifted to the $2 \theta=$ $25-30^{\circ}$ in fly ash based geopolymer pattern is due to formation of N-A-S-H (alkaline aluminosilicate hydrate gel) as the primary reaction product of geopolymerization reaction in the diffraction patterns of geopolymeric materials [31-34]. During activation of the original fly ash the crystalline phase remains unreactive and the amorphous (glassy) phase results in NASH gel as a main reaction product.

FESEM: The original fly ash contains a spherical particle during coal combustion process as shown in Fig. 5a. On activation of fly ash a dense continuous gel like structure is formed 

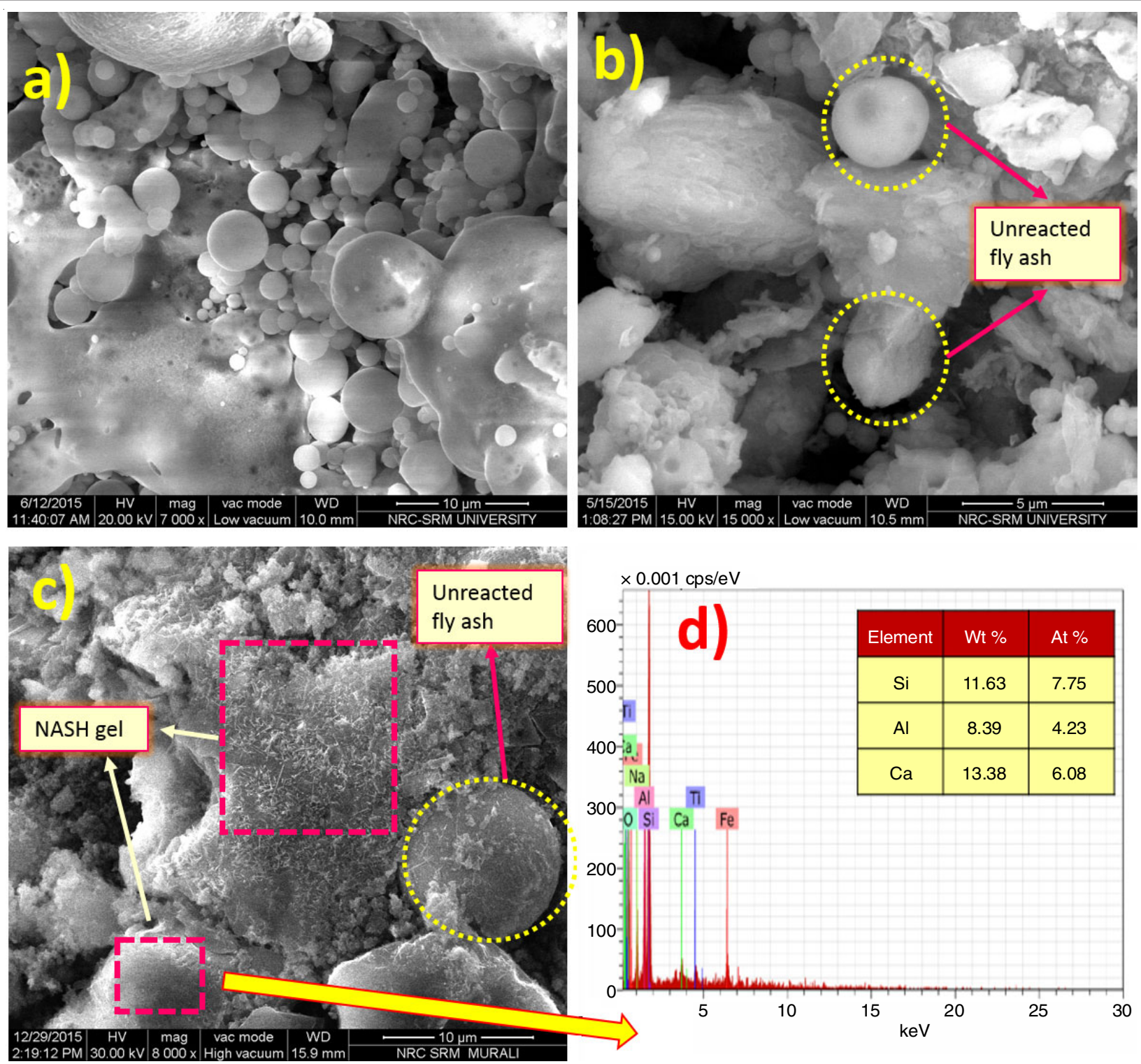

Fig. 5. FESEM micrograph of (a) FA (b) FG specimen at $24 \mathrm{~h}$ (c) FG specimen at 28 days (d) EDAX of FG specimen at 28 days of curing

over the surface of fly ash. Fig. 5b shows some unreacted fly ash at $24 \mathrm{~h}$ of curing with the formation of NASH gel. The number of unreacted particle is decreased on increasing the curing time due to formation dense gel structure with micropores. The formation of needle like structure adhered to the surface of gel may be due to high concentration of activating solution represented in Fig. $5 \mathrm{c}$. The primary reaction product contains a dense continuous gel over the surface of fly ash with micro-pores and needle like structure leads to fire resistant application. Fig. 5d shows the EDAX of fly ash mediated by alkaline solution and $\mathrm{Si} / \mathrm{Al}$ is found to be 1.386 .

TEM analysis: Fig. 6 shows TEM images of micro-sectioned fly ash based geopolymer. Fig. 6a shows the spherical fly ash particle undergoes a geopolymerization reaction process under alkaline environment for 28 days of curing and it is well ordered in hexagonal array. In addition to main geopolymeric gel product there will be some weakly crystalline NASH geopolymeric particles will be formed. These particles were found to be crystalline or semi-crystalline and observed in the diffraction patterns. Amorphous NASH geopolymeric gel was to be no regular shape.
The distance between two consecutive corners of the pores were calculated using TEM image is $0.34 \mathrm{~nm}$ (Fig. 6b). The diffraction pattern shows highly diffused with short range order and represented as two ring electron diffraction patterns. The diffraction pattern of Fig. 6c shows semi-crystalline and amorphous geopolymeric gel in it. The diffraction pattern with cloudy ring represent the presence of amorphous geopolymeric binding gel and with dotted ring shape denotes the semi-crystalline/ crystalline particles like quartz, mullite, etc. Fly ash mediated in alkaline environment shows the dissolution of silicate and aluminate species on its surface followed by polymerization resulting in geopolymeric binding gel (amorphous NASH network formation).

Thermogravimetric analysis: TGA is used to measure the weight loss as function of increasing temperature. Fig. 7 depicts that fly ash based geopolymer sample has a weight loss of $13 \%$ at $1200^{\circ} \mathrm{C}$. A sharp decrease is weight before 200 ${ }^{\circ} \mathrm{C}$ is attributed to the loss of both physically and part of chemically bound water molecule present in the product aluminosilicate polymer. There is no appreciable weight loss in between 

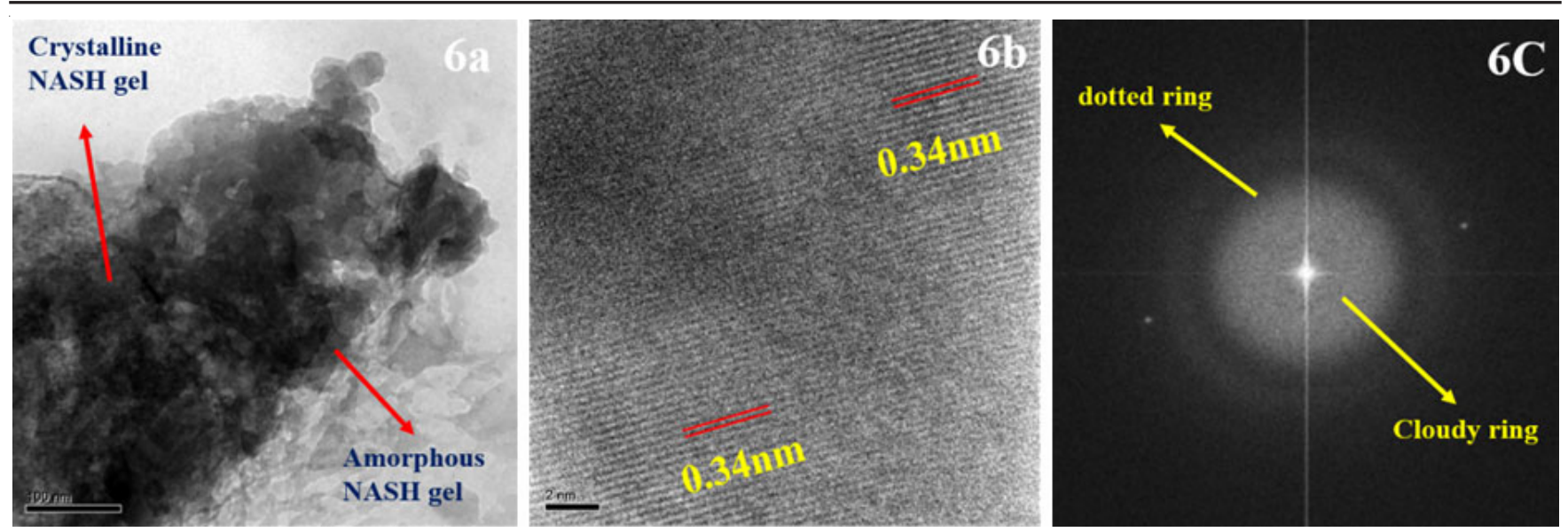

Fig. 6. TEM (a) FG specimen (b) short ordered NASH gel of (c) diffraction pattern of FG specimen

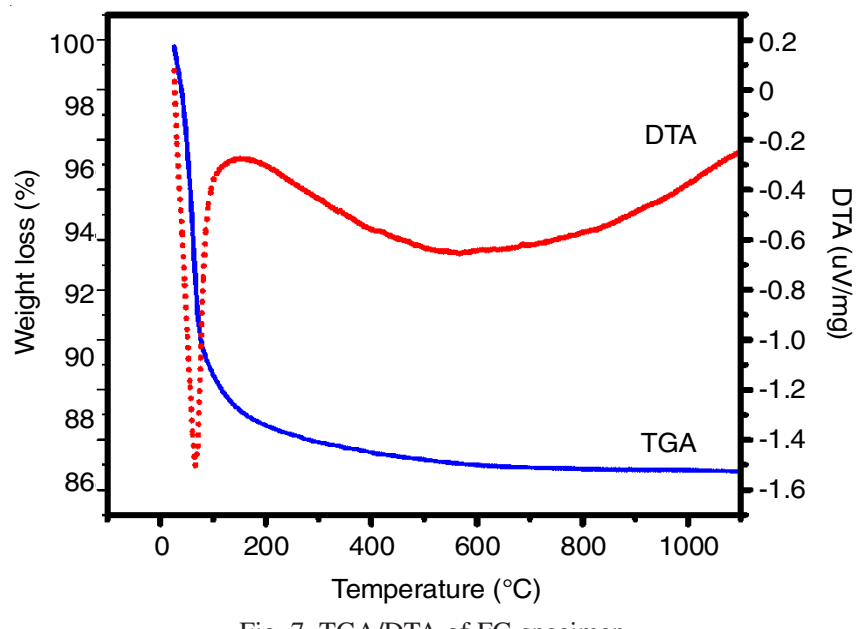

Fig. 7. TGA/DTA of FG specimen

200 to $1200{ }^{\circ} \mathrm{C}$. First endothermic peak around $50-150{ }^{\circ} \mathrm{C}$, a sharp decrease in weight attributed to the loss of evapourable water content from the binder gel N-A-S-H . The endothermic peak from the ambient temperature to $180^{\circ} \mathrm{C}$ centred at approximately $67^{\circ} \mathrm{C}$, correspondingly the weight loss of approximately $13 \%$ of fly ash based geopolymer specimen.

Zeta potential: Zeta potential is a scientific term for electrokinetic potential and a measure of magnitude of the electrostatic or charge repulsion/attraction between particles. A negative zeta potential was observed for fly ash, which contains reactive $\mathrm{Si}$ and $\mathrm{Al}$ groups. The highest negative value of zeta potential $(-18.8 \mathrm{mV})$ indicates the steadiness of geopolymer suspensions. On activation of original fly ash by alkali activator, hydroxyl group in alkali activator reacts with $\mathrm{Si}$ and $\mathrm{Al}$ to form either $\left[\mathrm{SiO}(\mathrm{OH})_{3}\right]^{-}$or $\left[\mathrm{SiO}_{2}(\mathrm{OH})_{2}\right]^{2-}$ and $\left[\mathrm{Al}(\mathrm{OH})_{4}\right]^{-}$[34]. The $\mathrm{Na}^{+}$ ions in alkali activator react with negatively charged species to form a sodium aluminosilicate hydrate gel layer, $\left[\mathrm{Na}_{\mathrm{z}}\left(\mathrm{AlO}_{2}\right)_{\mathrm{x}}\right.$ $\left.\left(\mathrm{SiO}_{2}\right)_{\mathrm{y}} \mathrm{nNaOH} \cdot \mathrm{mH}_{2} \mathrm{O}\right]$ results in decrease in zeta potential values $(-41.8 \mathrm{mV})$. The result obtained in the present study agrees with Gunasekaran et al. [35].

\section{Conclusion}

Chemical analysis through XRF, \% amorphous and crystalline phases through XRD and microstructural analysis of precursor and hardened matrix were carried out. Key spectroscopic techniques viz. ATR FT-IR, XRD, TGA/DTA, zeta potential and nuclear magnetic resonance spectroscopy were used to understand the network structures of gels formed during the reaction. The products formed were found to exhibit amorphous character with minor crystalline phases. The ATR FTIR spectra revealed the differences between fly ash before and after alkali activation. The main band corresponding to Si-O and Al-O vibrations of original fly ash was found to be displaced towards the lower values after reaction, besides showing the presence of active amorphous bonds in a major level for activation. In ${ }^{29} \mathrm{Si}$ MAS-NMR spectrum, the reaction products exhibited a 3D glassy structure with evidence of penetration of $\mathrm{Al}$ atoms into the original polymeric silicate structure of fly ash during activation reaction. The decrease in zeta potential value of fly ash based geopolymer indicates high chemical stability of fly ash in alkaline environment to form a primary reaction product (NASH gel) was reflected in the XRD phase change. A continuous dense gel structure with micro-pores with the decreasing rate of unreacted fly ash by increasing the curing period well agrees with the compressive strength of fly ash based geopolymer specimens. The properties of fly ash based geopolymer can be exploited for their application in the manufacture of cement, concrete, refractories, bricks, ceramics, thermal insulating material, sleepers of railway, structures restoration and in several fields of civil engineering.

\section{CONFLICT OF INTEREST}

The authors declare that there is no conflict of interests regarding the publication of this article.

\section{REFERENCES}

1. P.C. Aitcin, Cement Concr. Res., 30, 1349 (2000); https://doi.org/10.1016/S0008-8846(00)00365-3.

2. B. Akcay and M.A. Tasdemir, Constr. Build. Mater, 23, 353 (2009); https://doi.org/10.1016/j.conbuildmat.2007.11.015.

3. J.S. Damtoft, J. Lukasik, D. Herfort, D. Sorrentino and E.M. Gartner, Cement Concr. Res., 38, 115 (2008); https://doi.org/10.1016/j.cemconres.2007.09.008.

4. C. Shi, A.F. Jiménez and A. Palomo, Cement Concr. Res., 41, 750 (2011); https://doi.org/10.1016/j.cemconres.2011.03.016.

5. C.O. Ogunkunle and P.O. Fatoba, Pol. J. Environ. Stud., 22, 487 (2013).

6. M.C.G. Juenger, F. Winnefeld, J.L. Provis and J.H. Ideker, Cement Concr. Res., 41, 1232 (2011); https://doi.org/10.1016/j.cemconres.2010.11.012.

7. B. Suhendro, Procedia Eng., 95, 305 (2014); https://doi.org/10.1016/j.proeng.2014.12.190. 
8. J.S.J. Van Deventer, J.L. Provis and P. Duxson, Miner. Eng., 29, 89 (2012); https://doi.org/10.1016/j.mineng.2011.09.009.

9. J. Davidovits, Geopolymer Chemistry and Applications Book, Geopolymer Institute (2008).

10. A. Fernández-Jiménez, A. Palomo and M. Criado, Cement Concr. Res., 35, 1204 (2005); https://doi.org/10.1016/j.cemconres.2004.08.021.

11. P. Duxson and J.L. Provis, J. Am. Ceram. Soc., 91, 3864 (2008); https://doi.org/10.1111/j.1551-2916.2008.02787.x.

12. L. Weng and K. Sagoe-Crentsil, J. Mater. Sci., 42, 2997 (2007); https://doi.org/10.1007/s10853-006-0820-2.

13. N.P. Bansal, J.P. Singh, W.M. Kriven and H. Schneider, Ceram. Trans., 153, 175 (2003).

14. P.S. Singh, T. Bastow and M. Trigg, J. Mater. Sci., 40, 3951 (2005); https://doi.org/10.1007/s10853-005-1915-X.

15. J.P. Hos, P.G. McCormick and L.T. Byrne, J. Mater. Sci., 37, 2311 (2002); https://doi.org/10.1023/A:1015329619089.

16. M. Criado, A. Fernández-Jiménez, A. Palomo, I. Sobrados and J. Sanz, Micropor. Mesopor. Mater., 109, 525 (2008); https://doi.org/10.1016/j.micromeso.2007.05.062.

17. J. Davidovits, J. Therm. Anal., 37, 1633 (1991); https://doi.org/10.1007/BF01912193.

18. S. Onisei, Y. Pontikes, T. Van Gerven, G.N. Angelopolous, T. Levea, V. Predica and P. Moldovan, J. Hazard. Mater, 205-206, 101 (2012); https://doi.org/10.1016/j.jhazmat.2011.12.039.

19. Z. Zhang, H. Wang and J.J. Provis, Sustain. Cement-Based Mater, 1, 154 (2012); https://doi.org/10.1080/21650373.2012.752620.

20. D. Bondar, C.J. Lynsdale, N.B. Milestone, A.A. Ramezanianpour and N. Hassani, Cement Concr. Compos., 33, 251 (2011); https://doi.org/10.1016/j.cemconcomp.2010.10.021.

21. D.C.D. Nath, S. Bandyopadhyay, S. Gupta, A. Yu, D. Blackburn and C. White, Appl. Surf. Sci., 256, 2759 (2010); https://doi.org/10.1016/j.apsusc.2009.11.024.

22. P. Nayak and B.K. Singh, Bull. Mater. Sci., 30, 235 (2007); https://doi.org/10.1007/s12034-007-0042-5.
23. T. Yang, X. Yao, Z. Zhang and H. Wang, Sustain. Cement-Based Mater, 1, 167 (2012) https://doi.org/10.1080/21650373.2012.752621.

24. D. Bondar, C.J. Lynsdale and N.B. Milestone, ACI Mater. J., 110, 331 (2013),

25. N.J. Clayden, S. Esposito, A. Aronne and P. Pernice, J. Non-Cryst. Solids, 258, 11 (1999); https://doi.org/10.1016/S0022-3093(99)00555-4.

26. I. Lecomte, C. Henrist, M. Liegeois, F. Maseri, A. Rulmont and R. Cloots, J. Eur. Ceram. Soc., 26, 3789 (2006); https://doi.org/10.1016/j.jeurceramsoc.2005.12.021.

27. M. Sitarz, M. Handke and W. Mozgawa, Spectrochim. Acta Part A: Mol. Biomol. Spectrosc., 56, 1819 (2000); https://doi.org/10.1016/S1386-1425(00)00241-9.

28. O.A. Abdulkareem, M.M.A.B. Abdullah, K. Hussin, K.N. Ismail and M. Binhussain, Materials, 6, 4450 (2013); https://doi.org/10.3390/ma6104450.

29. O. Font, N. Moreno, X. Querol, M. Izquierdo, E. Alvarez, S. Diez, J. Elvira, D. Antenucci, H. Nugteren, F. Plana, A. López, P. Coca and F.G. Peña, Fuel, 89, 2971 (2010); https://doi.org/10.1016/i.fuel.2009.11.024.

30. S. Alonso and A. Palomo, Mater. Lett., 47, 55 (2001); https://doi.org/10.1016/S0167-577X(00)00212-3.

31. M.L. Granizo, S. Alonso, M.T. Blanco-Varela and A. Palomo, J. Am. Ceram. Soc., 85, 225 (2002); https://doi.org/10.1111/j.1151-2916.2002.tb00070.x.

32. X. Li, X. Ma, S. Zhang and E. Zheng, Materials, 6, 1485 (2013); https://doi.org/10.3390/ma6041485.

33. J. Temuujin, A. van Riessen and K.J.D. MacKenzie, Constr. Build. Mater, 24, 1906 (2010); https://doi.org/10.1016/j.conbuildmat.2010.04.012.

34. T. Revathi, R. Jeyalakshmi and N.P. Rajamane, Appl. Surf. Sci., 449, 322 (2018); https://doi.org/10.1016/j.apsusc.2018.01.281.

35. C. Gunasekara, D.W. Law, S. Setunge and J.G. Sanjayan, Constr. Build. Mater, 95, 592 (2015); https://doi.org/10.1016/j.conbuildmat.2015.07.175. 